\title{
Phenotypic characterization of Native Chicken reared under intensive management system
}

\author{
S. Faruque ${ }^{1}$, N. U. Siddiquee ${ }^{2}$, M. A. Afroz ${ }^{3}$ and M. S. Islam ${ }^{4}$ \\ ${ }^{1}$ Bangladesh Livestock Research Institute, Savar, Dhaka-1341, ${ }^{2}$ Upazilla Livestock Officer, Mymensingh Sadar, \\ Mymensingh-2200, ${ }^{3}$ Department of Animal Breeding and Genetics, Bangladesh Agricultural University, Mymensingh- \\ 2202 and ${ }^{4}$ Upazilla Livestock Officer, Ramgati, Lakshmipur
}

\begin{abstract}
The Phenotypic characteristics of three genotypes of native chicken comprising of Non-descript Desi (ND), Hilly (H) and Naked Neck (NN) were studied. A total of 180 individual chickens (Male: ND= 20; $H=20$ and NN=20; Female: $\mathrm{ND}=40, \mathrm{H}=40$ and $\mathrm{NN}=40$ ) were characterized under intensive management system for qualitative and quantitative traits. The results indicated that the predominant plumage color of three types of native chickens was black brownish (33.33\%) followed by white with black tips (28.33\%) and red brownish $(18.33 \%)$. Values indicate that $35 \%$ of native chickens had whitish shank color followed by yellowish $31.68 \%$; black $11.66 \%$ and others $21.67 \%$. All hens of ND, $\mathrm{H}$ and $\mathrm{NN}$ laid light brown $(62.42 \%)$ to cream or off white $(30.28 \%)$ colored eggs. Variations were also found on quantitative traits such as shank length, body weight and reproductive traits on intensive management system. number of eggs/ hen from starting to ten months of laying were 108, 104 and 112, respectively in ND, $\mathrm{H}$ and NN genotypes. Three native chicken genotypes showed distinct physical variations for both qualitative and quantitative traits under intensive management system.
\end{abstract}

Keywords: Native chicken, Quantitative traits, Qualitative traits

\section{Introduction}

Native chicken have several valuable characters that are not found in "exotic" chicken and appropriate traditional low input/low output farming system. Most of the original chicken in Bangladesh are of nondescript except few game bird like Sarail Aseel and Chittagong (Malay). These indigenous chicken types have a good adaptability for climate and resistance against diseases. There is wide variability in respect of performance in these chicken types. The improvement of domestic animals including chickens to meet human needs is dependent on variations (variations within and between breeds). Such variation among individuals or groups of chickens gives room and opportunity for breeding and selection. Limited work pertaining to the phenotypic and genotypic constitution of the indigenous chicken of Bangladesh was carried out (Okada, et al. 1988; Huque, et al. 1993 and Ali and Faruque, 1998). Thus the present study was aimed for phenotypic characterization and to know about some quantitative characteristics of three indigenous chicken genotypes reared in Poultry Farm of Bangladesh Livestock Research Institute (BLRI) based on some phenotypic traits.

\section{Materials and Methods}

The experiment was carried out at poultry farm, Poultry Production Research Division, Bangladesh Livestock Research Institute, Savar, Dhaka to study the phenotypic characteristics of three genotypes of native chicken comprising of non-descript Desi (ND), Hilly (H) and Naked Neck (NN). Sixty birds (40 females and 20 males) of about 80 weeks age from each genotype were randomly selected to record the quantitative traits. Body length was determined by measuring the length from beak to toe with a measuring tape. Comb and wattle length were measured using a measuring tape as a distance between the upper and the lower point of the organ. Semen was collected by abdominal massage technique. Egg production was recorded on hen day basis and egg wt. was taken by egg measuring balance. Ejaculate volume $(\mathrm{ml})$ was measured using $1 \mathrm{ml}$ pipette. Shank length was determined by measuring the length from top of hock joint to the footpad. The data collected from the quantitative variables were analyzed to obtain descriptive statistics, using General Linear Model (GLM) multivariate analyses (SPSS, 1996). Similarly, the qualitative parameters were analyzed using descriptive statistics and compared as percentages using the same software package. 


\section{Results and Discussion}

Qualitative traits such as plumage colour, comb colour, shank colour, earlobe colour and egg colour were evaluated in three types of native chickens under intensive management system (Table 1). The results indicated that the predominant plumage colour of three types of native chickens was black brownish $(33.33 \%)$ followed by white with black tips $(28.33 \%)$ and red brownish $(18.33 \%)$. Non-descript Desi chickens have no definite plumage colour. Black brownish constituted the maximum proportion (40\%) of plumage colour followed by red brownish (35\%). Hilly birds are covered with plumage of white with black tips $(85 \%)$ followed by multicolour $(15 \%)$. Naked Neck birds are very colourful-black brownish, multicolour, red brownish and black feather combinations were found. The presence of such large variations in plumage colours revealed that much genetic dilutions have occured with native chickens which is about $60 \%$ (Bhuiyan et al., 2005). No variations were observed in comb type and shank feather among three types of native chcickens. The comb type of ND, $\mathrm{H}$ and NN was $100 \%$ single and in $100 \%$ cases, no feather was observed in the shank. The shank colour of ND was $40 \%$ white or whitish. While, the shank colour of $\mathrm{H}$ was whitish $35 \%$; yellowish $25 \%$ and others $35 \%$. The highest proportion of shank colour of NN was $45 \%$ yellowish followed by whitish $30 \%$ and black $15 \%$. The overall mean indicated that $35 \%$ of native chickens had whitish shank colour followed by yellowish $31.68 \%$; black $11.66 \%$ and others $21.67 \%$. The results are not consistent with the observations of Bhuiyan et al. (2005) and Ahmed and Ali (2007). Variations were also observed in earlobe colour and eggshell colour. The earlobe colour of ND and $\mathrm{H}$ was $80 \%$ white followed by red and admixture of red and white. These results are similar to the findings of the highest proportion Ahmed and Ali (2007) who found $80.55 \%$ white earlobe colour of Desi chicken.

Table 1. Morphological characteristics of Native chicken under intensive management system

\begin{tabular}{|c|c|c|c|c|}
\hline Parameters (\%) & ND & $\mathrm{H}$ & $\mathrm{NN}$ & Over all mean \\
\hline Sample size & 40 & 40 & 40 & \\
\hline \multicolumn{5}{|l|}{ Plumage color } \\
\hline Black & 5 & - & 10 & 5.00 \\
\hline Black Brownish & 40 & - & 60 & 33.33 \\
\hline Multicolor & 15 & 15 & 5 & 11.67 \\
\hline White with black tips & - & 85 & - & 28.33 \\
\hline Red brownish & 35 & - & 20 & 18.33 \\
\hline White with red stripes & 5 & - & - & 1.67 \\
\hline Brown & - & - & 5 & 1.67 \\
\hline \multicolumn{5}{|l|}{ Comb type } \\
\hline Single & 100 & 100 & 100 & 100.00 \\
\hline Rose & - & - & - & \\
\hline Pea comb & - & - & - & \\
\hline Comb Color & - & - & - & \\
\hline Red & 70 & 55 & 40 & 55.00 \\
\hline Brown & 20 & 30 & 55 & 35.00 \\
\hline Pale & 10 & 15 & 5 & 10.00 \\
\hline \multicolumn{5}{|l|}{ Shank feather } \\
\hline \multicolumn{5}{|l|}{ Present } \\
\hline Absent & 100 & 100 & 100 & 100.00 \\
\hline \multicolumn{5}{|l|}{ Shank color } \\
\hline White/whitish & 40 & 35 & 30 & 35.00 \\
\hline Black & 15 & 5 & 15 & 11.67 \\
\hline Yellow & 25 & 25 & 45 & 31.67 \\
\hline Greenish & 20 & 35 & 10 & 21.67 \\
\hline \multicolumn{5}{|l|}{ Ear lobes color } \\
\hline Red & 5 & - & - & 1.67 \\
\hline White & 80 & 80 & 45 & 68.33 \\
\hline Admixture of red and white & 10 & 15 & 35 & 20.00 \\
\hline yellow & - & - & 20 & 6.67 \\
\hline Others & 5 & 5 & - & \\
\hline \multicolumn{5}{|l|}{ Egg shell color } \\
\hline White & 61.60 & 69.05 & 56.61 & 62.42 \\
\hline Brown & 7.70 & 4.76 & 9.44 & 7.30 \\
\hline Cream & 30.70 & 26.19 & 33.96 & 30.28 \\
\hline
\end{tabular}


But dissimilar to the results of Biswas (2005) who found red earlobe colour of Desi chicken was $58 \%$ followed by white earlobe of $45.8 \%$. The highest proportion of earlobe colour in NN was $45 \%$ white followed by $35 \%$ admixture of red and white and yellow $20 \%$. All hens of ND, $\mathrm{H}$ and NN laid light brown $(62.42 \%)$ to cream or off white $(30.28 \%)$ coloured eggs. However, considerable numbers of chickens laid white coloured eggs accounted for $7.30 \%$. It was reported that the indigenous chickens in Bangladesh laid light brown (67\%) and white (27\%) eggs (Bhuiyan et al. 2005), which is more or less similar to the results of our findings. Body weight, body length, shank length, wattle length and semen volume are shown in Table 2. Data presented in Table 2 showed that the live performance parameters as affected by genotype. There was highly significant difference among genotypes for body weight, shank length, wattle length and semen volume. In terms of shank length, the Hilly cocks had shank length of $11.09 \mathrm{~cm}$ at 80 weeks of age, which was significantly longer compared to the other genotypes in this study. Significantly $(P<0.01)$ the highest wattle length was observed in Naked Neck genotype.

Table 2. Shank length, wattle length, body length, body weight and semen volume of Non-descript Desi, Hilly and Naked Neck males

\begin{tabular}{|c|c|c|c|c|}
\hline \multirow[t]{2}{*}{ Parameter } & \multicolumn{3}{|c|}{ Genotype } & \multirow{2}{*}{$\begin{array}{l}\text { F-value and level of } \\
\text { significance }\end{array}$} \\
\hline & ND & $\mathrm{H}$ & NN & \\
\hline Shank Length $(\mathrm{cm})$ & $10.35^{b}$ & $11.09^{\mathrm{a}}$ & $11.09^{\mathrm{a}}$ & $5.493^{* \pi}$ \\
\hline Wattle length $(\mathrm{cm})$ & $4.98^{\mathrm{a}}$ & $4.09^{b}$ & $5.12^{\mathrm{a}}$ & $6.333^{* *}$ \\
\hline Body length $(\mathrm{cm})$ & $43.64^{\mathrm{ab}}$ & $45.74^{a}$ & $43.21^{\mathrm{b}}$ & $3.145^{\mathrm{NS}}$ \\
\hline Body weight $(\mathrm{kg})$ & $2.48^{\mathrm{a}}$ & $2.60^{\mathrm{a}}$ & $2.15^{\mathrm{a}}$ & $9.007^{* \pi *}$ \\
\hline Semen volume $(\mathrm{ml})$ & $0.213^{b}$ & $0.224^{b}$ & $0.371^{\mathrm{a}}$ & $5.493^{* \pi}$ \\
\hline $\begin{array}{l}\text { Correlation coefficient between shank length with body } \\
\text { weight }\end{array}$ & $0.60^{* * *}$ & 0.64 & $0.48^{*}$ & \\
\hline $\begin{array}{l}\text { Correlation coefficient between shank length with } \\
\text { semen volume }\end{array}$ & -0.15 & -0.12 & $0.45^{*}$ & \\
\hline $\begin{array}{l}\text { Correlation coefficient between body weight with } \\
\text { semen volume }\end{array}$ & 0.019 & -0.40 & $0.63^{* \pi}$ & \\
\hline
\end{tabular}

${ }^{*}(P<0.05)^{\star \star}(P<0.01)^{\star \star \star}(P<0.001) ;{ }^{\text {a,b.c }}$ Means within rows with different superscripts differ significantly

There was highly significant difference among genotypes for semen volume. Significantly positive relationship between body weight and shank length was observed in all genotypes. Non-significant negative relationship between shank length and semen volume was observed in non-descript Desi and Hilly genotypes, except Naked Neck genotype whereas the association between shank length and semen volume was significantly positive $(r=0.45)$. The present result indicated that the live body weight was significantly negatively correlated with semen volume in Hilly genotype $(r=-0.40)$ but positively correlated in Naked Neck genotype ( $r=0.63$ ). Several authors (Harris et al., 1984; Marks, 1985 and Slegel and Dunnington, 1985) observed a positive relationship between live body weight and semen volume. Inversely, Scogin et al., (1982) found a negative correlation between body weight and semen volume. Day-old weight $(\mathrm{g})$, body weight $(\mathrm{g})$, shank length, comb length and other reproductive traits are presented in Table 3. The non-descript Desi hens were significantly heavier than the other two genotypes $(\mathrm{P}<0.001)$. But body length did not differ significantly among the genotypes. In terms of shank length, the Non-descript Desi and Hilly hens had shank lengths of $9.63 \mathrm{~cm}$ and $9.20 \mathrm{~cm}$, respectively at 80 weeks of age, which is relatively long compared to Naked Neck genotype. As to comb length, the Non-descript Desi and Naked Neck hens had significantly largest comb length than Hilly. Other economical traits that showed morphological variation were body weight at day-old (28.56-29.83 g), age at first egg (21.7322.44 wks.), egg weight (40.32-44.15g), fertility (84.98-91.55\%), hatchability on fertile eggs $57.66-88.63$ $\%$ ). Number of egg/ hen from starting to ten months of laying were 108, 104 and 112, respectively in ND, $\mathrm{H}$ and NN genotypes. Sazzad (1992) in Bhuiyan et al. (2009) reported that egg laying potential could be increased to 64 eggs/hen/year under intensive conditions. But in our study it was observed that on an average egg laying performance could be increased to 108 eggs/hen from starting to ten months of laying. This result was much higher than the Sazzad (1992). Fitzpatnick and Ahmed (2000) in Bhuiyan et al. (2009) stated that the mother of all these chickens, the Red Jungle Fowl, used to lay only 5-6 eggs/hen/production cycle. This reveals that egg production have been increased many fold due to genetic dilution of various level (Bhuiyan et al., 2009). So, molecular characterization is of prime importance. 
Table 3. Comparison of economically important traits (performance profile) among native chickens

\begin{tabular}{|l|c|c|c|c|}
\hline \multirow{2}{*}{ Traits } & \multicolumn{3}{|c|}{ Genotype } & $\begin{array}{c}\text { Over all } \\
\text { mean }\end{array}$ \\
\cline { 2 - 5 } & ND & $H$ & NN & 29.30 \\
\hline Day-old wt (g) & $29.83^{\mathrm{a}}(342)$ & $28.56^{\mathrm{b}}(205)$ & $29.49^{\mathrm{a}}(143)$ & 2.54 \\
\hline Body weight (kg) & $1.61^{\mathrm{a}}(40)$ & $1.58^{\mathrm{ab}}(40)$ & $1.43^{\mathrm{b}}(40)$ & 1.54 \\
\hline Body Length (cm) & $37.03(40)$ & $37.12(40)$ & $37.07(40)$ & 37.07 \\
\hline Shank length (cm) & $9.63^{\mathrm{a}}(40)$ & $9.20^{\mathrm{ab}}(40)$ & $8.86^{\mathrm{b}}(40)$ & 9.23 \\
\hline Comb Length (cm) & $5.21(40)$ & $4.97(40)$ & $5.08(40)$ & 5.08 \\
\hline Age at first egg (wks.) & $22.44^{\mathrm{a}}(109)$ & $22.17^{\mathrm{ab}}(47)$ & $21.73^{\mathrm{b}}(81)$ & 22.11 \\
\hline Egg production (no) (from starting to 10 months & $108(148)$ & $104(75)$ & $112(63)$ & 108 \\
\hline Egg weight (g) & $42.94^{\mathrm{b}}(187)$ & $40.32^{\mathrm{C}}(89)$ & $44.15^{\mathrm{a}}(35)$ & 42.47 \\
\hline Fertility (\%) & 89.65 & 91.55 & 84.98 & 88.72 \\
\hline Hatchability (\%) & 88.63 & 79.23 & 57.66 & 75.03 \\
\hline
\end{tabular}

a,b.c Means within rows with different superscripts differ significantly *Values in the parentheses indicate the number of observations

\section{Conclusion}

From this study it may be concluded that three genotypes of native chickens had distinct physical variations for both qualitative and quantitative traits under intensive management conditions. There is a scope to improve native chicken and further research is needed to explore full potentiality of indigenous chicken by conservation and molecular characterization.

\section{References}

Ahmed, S.T. and Ali, M.A. 2007. Performance of Synthetic, Desi, Synthetic $x$ Desi and Synthetic $x$ Star cross brown chicken at marketing. Proceedings of the $5^{\text {th }}$ International Poultry Show and Seminar. Organized by World's Poultry Science Association. Bangladesh Branch, 01-03 March 2007, pp. 18-25.

Ali, A. and Faruque, M.O. 1998. Poultry improvement strategies in Bangladesh. First National Workshop on Animal Breeding, Bangladesh Agricultural University, Mymensingh.

Bhuiyan, A.K.F.H., Bhuiyan, M.S.A. and Deb, G.K. 2005. Indigenous chicken genetic resources in Bangladesh: Current status and future outlook. Animal Genetic Resources Information (AGRI), FAO, Rome, Italy: 36: 73-84.

Bhuiyan, A.K.F.H., Biswas, S.R. and Biswas, J.C. 2009. Genetic dilution of indigenous chicken in selected villages of Bangladesh. In Proc. of the Sixth International Poultry Show and Seminar, WPSA-BB, 5-7 March 2009, Dhaka, Bangladesh: 147-162.

Biswas, S.R. 2005. Genetic dilution of indigenous chicken in selected villages. M.S. Thesis, Department of Poultry Science, Bangladesh Agricultural University, Mymensingh.

Fitzpatrick, D.M. and Ahmed, K. 2000. Red roving fowl. Down to Earth Science and Environment Forthnightly, 9: 28-30.

Harris, G.C., Benson J.A. and Sellers, R.S. 1984. The influence of day length, body weight and age on the productive ability of broiler breeder cockerels. Poult. Sci., 63: 1705-1710.

Huque, Q.M.E., Hossain, M.J. and Huque, M.E. 1993. Growth pattern of Assel birds under intensive system. Bang. J. Live. Res. Vol.1, No.1.

Marks, H.L. 1985. Direct and correlated response to selection for growth: In: Hill, W.G., J.M. Manson and D. Hewitt, editors. Poultry Genetic and Breeding. Br. Poult. Sci. Symp., 18.

Okada, I., Maeda, Y., Hashiguchu, T., Hasnath, M.A., Faruque, M.O. and Majid, M.A. 1998. Gene constitution of indigenous chickens in Bangladesh. Japanese Poultry Science. 25(1): 15-26.

Sazzad, M.H. 1992. Comparative study on egg production and feed efficiency of different breeds of poultry under intensive and rural conditions in Bangladesh. Livestock Research for Rural development 4: 65-69.

Scogin, V., Harris, G.C., Sellers, R. Jr., Parker, J. and Goto, K. 1982. Effect of environmental temperature, feeding program and body weight on semen production and certain blood parameters of broiler breeders. Poult. Sci., 61: 1395 (Abstract).

Siegel, P.B. and Dunnington, E.A. 1990. Reproductive complications associated with selection for broiler growth. In: Hill, W.G., J.M. Manson and D. Hewitt, editors. Poultry Genetic and Breeding. Br. Poult. Sci. Symp., 18.

SPSS (Statistical Procedures For Social Sciences). 1996. SPSS 10.0 for windows. 